\title{
Defining organominerals: Comment on 'Defining biominerals and organominerals: Direct and indirect indicators of life' by Perry et al. (2007, Sedimentary Geology, 201, 157-179)
}

Christian Défarge ${ }^{\mathrm{a}, \mathrm{b}, *}$, Pascale Gautret ${ }^{\mathrm{a}}$, Joachim Reitner $^{\mathrm{c}}$, Jean Trichet ${ }^{\text {a }}$

\author{
${ }^{a}$ Institut des Sciences de la Terre d'Orléans, Unité Mixte de Recherche 6113, \\ C.N.R.S.-Université d'Orléans, 45067 Orléans cedex 2, France \\ ${ }^{b}$ Ecole Polytechnique de l'Université d'Orléans, 45072 Orléans cedex 2, France \\ ${ }^{c}$ Göttingen Zentrum Geowissenschaften, Abteilung Geobiologie, Universität Göttingen, \\ Goldschmidtstrasse 3, D-37077 Göttingen, Germany
}

\begin{abstract}
The paper by Perry et al. (2007, Defining biominerals and organominerals: Direct and indirect indicators of life, Sedimentary Geology, 201, 157-179) proposes to introduce "the new term 'organomineral"' to describe mineral products whose formation is induced by byproducts of biological activity, dead and decaying organisms, or nonbiological organic compounds, to be distinguished from the biomineral components of living organisms. The substantive 'organomineral', however, is not new: it was first introduced in 1993, with basically the same definition and distinction from biominerals, at the 7th International Symposium on Biomineralization (Défarge and Trichet, 1995, From biominerals to

\footnotetext{
${ }^{*}$ Corresponding author. Ecole Polytechnique de l'Université d'Orléans, 8 rue Léonard de Vinci, 45072 Orléans cedex 2, France. Fax: 33/0-238-41-73-29. E-mail: Christian.Defarge@univ-orleans.fr
} 
'organominerals': The example of the modern lacustrine calcareous stromatolites from Polynesian atolls, Bulletin de l'Institut Océanographique de Monaco, nº spéc. 14, vol. 2, pp. 265-271). Thereafter, more than twenty-five papers by various authors have been devoted to organominerals and organomineral formation ('organomineralization') processes. Only two of these papers are cited by Perry et al., and without any reference to the definitions, or even the terms 'organomineral' or 'organomineralization', which they included. Moreover, Perry et al. tend to enlarge the original concept of organomineral to encompass all minerals containing organic matter, whether these organic compounds are active or passive in the mineralization, which introduces ambiguities detrimental to a fine understanding of present and past geobiological processes. Finally, Perry et al. propose to consider organominerals as indirect biosignatures that could be used in the search for evidence of life in the geological record and extraterrestrial bodies. This latter proposition also is problematical, in that organominerals may be formed in association with prebiotic or abiotic organic matter.

Keywords: Organominerals; Organomineralization; Terminology; History of science; Search for life; Biosignatures

\section{Introduction}

The paper by Perry et al. (2007) is a laudable attempt to review modern and fossil examples of organominerals (minerals formed under the influence of by-products of biotic activity, dead and decaying organisms, or nonbiological organic compounds) and to distinguish them from biominerals (formed under the direct influence and control of living organisms). It is also valuable for reaffirming that processes of organomineral formation should be taken into account in astrobiological studies on the search for life. 
However the paper does not include fundamental references on the subject, in particular on former definitions and examples of organominerals. These omissions limit the interest of their contribution, especially as it claims a terminological and epistemological purpose. Moreover the authors tend to enlarge previous definitions of organomineral and organomineral formation concepts, which introduces ambiguities that are detrimental to a fine understanding of these geobiological objects and processes, instead of any clarification.

\section{Short history of 'organomineral’ definition}

Perry et al. (2007) propose to introduce "the new term 'organomineral"' (pp. 157-158) to describe mineral products whose formation is induced by by-products of biological activity, dead and decaying organisms, or nonbiological organic compounds. The authors distinguish organominerals from biominerals that are formed by the uptake of elements and their incorporation into mineral structures under direct biological control (Perry et al., 2007, p. 158).

The substantive 'organomineral', however, was introduced by two of us in 1993, with basically the same definition and distinction from biominerals, in a special session of the 7th International Symposium on Biomineralization devoted to the formation of minerals in association with 'free organic compounds' (Défarge and Trichet, 1995). The term 'organomineralization' was also introduced at the same conference to designate the processes of formation of organominerals, with illustrations including (Défarge and Trichet, 1995; Trichet and Défarge, 1995): (i) precipitation of calcium carbonate micrite clusters within the alveoli, on the wall surfaces of a honeycomb-like sedimentary organic network formed through the reorganization of extracellular polymer secretions (EPS) of cyanobacteria in modern stromatolites; (ii) post-mortem encrustation of cyanobacterial filaments in the same 
stromatolites; (iii) formation of calcium phosphate pellets under the influence of planktonic sedimentary organic matter in marine deposits; (iv) diagenetic calcification of gastropod fecal pellets in lacustrine sediments; (v) lithification of decaying fish organs by calcium salts of fatty acids; (vi) post-mortem pyritization of soft tissues of trilobites; (vii) intervention of organic compounds in the crystallization of aluminum and iron oxides and hydroxides in natural waters and soils; (viii) precipitation of metal minerals, principally oxides and sulfides, following the demixion of organo-metallic complexes submitted to natural or experimental geothermal heating between 100 and $300^{\circ} \mathrm{C}$; and (ix) in vitro formation of carbonate ooids in the presence of organic matter rich in acidic groups. Perry et al. (2007) cannot be unaware of these former definitions and examples, since one of the co-authors, Carole C. Perry (Harrison), was among the contributors (Harrison and Shaw, 1995) to the special session on 'free organic compounds' convened by one of us at this symposium (Trichet, 1995).

Thereafter, examples of organominerals and organomineralization processes have been documented, and the former papers cited, in mainstream scientific literature, beginning with our own work on carbonate organomineral formation in modern and recent microbialites and ooids (Défarge et al., 1996; Reitner et al., 1997; Arp et al., 1999; Trichet et al., 2001; Arp et al., 2003; Gautret et al., 2004; Gautret and Trichet, 2005), ancient microbialite analogues (Camoin et al., 1999; Tribovillard et al., 1999, 2000), mud mounds (Neuweiler et al., 1999), encrusting sponge cements (Russo et al., 2006), housing tubes of worms (Fischer et al., 2000), coral EPS (Reitner, 2005), decaying sponge tissues (Delecat et al., 2001), and during laboratory experiments with microbialite-, ooid- and meteorite-extracted organic matter (Reitner, 2004). Organominerals and organomineralization processes have also been brought up in a discussion, involving one of us, about the origin of lower Paleozoic carbonate mud (Pratt, 2001; Arp et al., 2002). Riding (2000), Winsborough (2000), Schlager (2003), then Dupraz et al. (2004) and Dupraz and Visscher (2005), cited organomineralization among the 
principal processes leading to carbonate precipitation in microbial mats and biofilms, or more widely in benthic marine sediments. Sprachta et al. (2001) provided further illustrations of carbonate organomineral formation in modern microbialites. Golubic et al. (2006) showed that organomineralization processes were probably involved in the fossilization of Cretaceous Scytonema-related cyanobacteria during their post-burial diagenesis. Riding (2000) and Gautret and Trichet (2005) are quoted by Perry et al. (2007), but without any reference to the definitions or mention of organominerals or organomineralization processes which they included.

\section{Organominerals and the search for life}

As indicated by the title of their paper, the main aim of Perry et al. (2007) is to add organominerals to the list of biosignatures to be used in the search for evidence of life in the terrestrial rock record, meteorites and extraterrestrial planets. According to these authors, organominerals should be treated as indirect indicators of life, while biominerals are direct ones (Perry et al., 2007, p. 157).

The subject of the potential occurrences of organominerals in extraterrestrial bodies, and of their use as biosignatures, however, has already been extensively discussed by one of us in a paper (Reitner, 2004) that is not cited by Perry et al. (2007). This discussion was notably supported by laboratory experiments of calcium carbonate precipitation in the presence of organic matter extracted from the Murchison CM2 meteorite: the meteorite organic compounds have been shown to be able to induce the formation of carbonate particles whose morphologies are similar to coccoid- or rod-shaped mineral bodies found in other meteorites, or to terrestrial carbonate peloids or dumbbells formed in association with 
bacterial EPS (Reitner, 2004). Reitner (2004), however, underlined the probable abiotic origin of the meteorite organic compounds.

\section{Necessity of a precise definition of organominerals}

\subsection{General considerations}

One of the reasons for the bibliographic omissions by Perry et al. (2007), and for their terminological focus on the objects (organominerals) rather than on the processes (organomineralization), might be that the authors introduce nuances in the definition of organominerals and tend to enlarge it: In the Introduction, organominerals are simply defined as "mineral products containing organic carbon" (Perry et al., 2007, p. 158). However, as the authors themselves later point out (Perry at al., 2007, p. 161), the presence of organic matter in a mineral does not mean that these organic compounds have played a role in crystallization: they could have been passively entombed or complexed during crystal growth. While the precise role of intramineral organic compounds is of little importance for some aspects of astrobiological studies (when the presence of organic matter can be interpreted as a biosignature), the distinction between passive and mineralization-active organic compounds remains fundamental for the other branches of geobiology, in particular for the understanding of present and past sedimentological processes and biogeochemical cycles (Dupraz and Visscher, 2005), and for potential engineering applications of organic-mineral interactions (Nealson and Ghiorse, 2001; Davies et al., 2003; Naylor, 2005).

Further, Perry et al. (2007, p. 160) state that the distinction proposed between organominerals and biominerals is simply a more precise differentiation between, respectively, "biologically induced" and "biologically controlled" minerals sensu Lowenstam 
and Weiner (1989). However, biologically induced mineralization, which designates the biomineralization "processes that are not specifically designed for mineralization, but do in fact result in mineral being formed" (Lowenstam and Weiner, 1989, p. 26), did not originally include processes of mineral formation in association with dead organisms, by-products of decaying organisms, or sedimentary organic relics. Moreover, in a geological perspective, it remains necessary to distinguish between mineralization processes linked to contemporaneous biological activity, and processes involving mineralizing organic compounds remote in space and time from the organisms which they derive from, as in the examples of carbonate sediments, soil Al and Fe oxides and hydroxides, and metal minerals derived from geothermal heating of organo-metallic complexes that are cited by Trichet and Défarge (1995). The original definitions of organominerals and organomineralization processes by Défarge and Trichet (Défarge and Trichet, 1995; Trichet and Défarge 1995) aimed to point out that, apart from biomineralizing living organisms, organic matrices and compounds inherited from living organisms may retain mineralizing properties after they have been released in water and incorporated in soils, sediments and rocks.

Other ambiguities are also detrimental to illustrations of organominerals given by Perry et al. (2007): Bacterial encrustations are redefined as organominerals rather than as biominerals, although it is noted that an improved understanding of the mechanisms of these encrustations may in the future lead to classify part of them in biominerals (Perry et al., 2007, pp. 161 and 167-168). Hot-spring siliceous sinter deposits are classified in organominerals only because their formation is a complex interplay of multiple physical, chemical and biological factors (Perry et al., 2007, p. 167). Carbonate stromatolites also are considered as organominerals (Perry et al., 2007, p. 169), whereas they are known to be organosedimentary deposits composed, for their in situ-precipitated parts, of a continuum of minerals ranging from micrite organominerals to biologically controlled biominerals, and including post- 
mortem encrusted organisms and biologically induced biominerals (Défarge and Trichet, 1995; Défarge et al., 1996; Riding, 2000).

In the Summary, Perry et al. (2007, p. 172) finally define organominerals as "combination[s] of organic substances produced in association with living organisms and 'non-living' byproducts", which is the vaguest definition of the whole paper. In this concluding definition of organominerals, the authors add to those natural terrestrial organominerals, the "meteorites and manufactured chemicals [...] derived from organic matter compounds not produced by life" (Perry et al., 2007, p. 172). However, in a geobiological perspective (Nealson and Ghiorse, 2001), a number of such manufactured organominerals should be regarded as biominerals because they are formed by the uptake of elements and their incorporation into mineral functional structures under direct biological (human) control (Dujardin and Mann, 2002; Davies et al., 2003).

In contrast with the biomineral concept, the category 'organomineral' sensu Perry et al. (2007) thus includes objects whose nature is unclear, or whose mechanism of formation remains unknown or might be reconsidered in the future. This confusion is paradoxical, because the authors rightly stress the necessity and importance of exact terminology for the advancement of science, and aimed to increase the accuracy of current usage (Perry et al., 2007, pp. 157-159 and 174). The original definition of organominerals by Défarge and Trichet (Défarge and Trichet, 1995; Trichet and Défarge, 1995), in contrast, precisely designates minerals whose formation is unequivocally mediated by organic compounds outside and independently from the living organisms from which these compounds may derive. This definition preserves Lowenstam and Weiner's (1989) definitions of biominerals, and the distinction between biologically controlled and biologically induced subcategories (Schlager, 2003; Reitner, 2004), which also remain useful. The continuum 'biologically controlled biominerals - biologically induced biominerals - organominerals formed under the influence 
of organic compounds independently from living organisms' is sufficient to cover the whole realm of mineralizing organic-mineral interactions.

If a new, broader definition of organominerals becomes necessary, it should include all minerals whose formation is unequivocally influenced, either thermodynamically, chemically, stereochemically, or spatially, by organic compounds. In this sense, the natural biologically controlled biominerals sensu Lowenstam and Weiner (1989), for example, are not distinct from organominerals, but a subcategory of organominerals notably characterized by precise delineated spaces of formation, cellular controls on crystal nucleation and growth, and specific habits (Lowenstam and Weiner, 1989), whose emergence from organomineralization processes can be searched for in the geological record (Bengtson, 1994; Kirschvink and Hagadorn, 2000). Biologically induced biominerals, sedimentary organominerals, prebiotic organominerals, or manufactured organominerals, are other subcategories of organominerals that can be scientifically distinguished. Minerals containing organic carbon should not be considered as organominerals until the role of organic compounds in their mineralization can be proved.

\subsection{Applications to the search for life}

Even in the proposed applications of the organomineral concept to the search for life in the Earth rock record and extraterrestrial bodies, the paper by Perry et al. (2007) is ambiguous and unsatisfactory. The biologically induced minerals sensu Lowenstam and Weiner (1989) still were indicators of life without being redefined as organominerals. Rock coatings reminiscent of desert varnish cannot be considered as indicators of life simply because they have been renamed organominerals (Perry et al., 2007, p. 173), inasmuch as the authors themselves show that silica glazes are a subcategory of desert varnish whose 
formation is abiotic (Perry et al., 2007, pp. 166-167). The minerals formed in association with abiogenic organic matter in carbonaceous meteorites, that are included by Perry et al. (2007, pp. 160 and 172) in organominerals, cannot, by definition, be used as indicators of life either. The authors themselves admit that the category organomineral should be subdivided, depending on the biotic or abiotic origin of the organic components (Perry et al., 2007, pp. 160 and 172).

Reitner (2004) already pointed out that meteorites might contain abiotic organomineral products, which thus could not be regarded as biosignatures. Other authors have also shown that nonbiological organic molecules may induce the formation of minerals resembling the components of extraterrestrial bodies that are interpreted as biologically induced minerals, in particular fossilized 'nan(n)obacteria' (Kirkland et al., 1999; Cisar et al., 2000; Vali et al., 2001). Organominerals sensu Défarge and Trichet (1995), and more generally organiccontaining minerals, cannot be considered as indicators of life until the biotic origin of their organic components and their mechanism of formation have been unequivocally deciphered. In an astrobiological perspective, it remains necessary to distinguish between minerals associated with by-products of life, minerals formed through prebiotic processes, and minerals that could have served as matrices for the prebiotic or abiotic formation of associated organic compounds (Westall et al., 2000; Vali et al., 2001; Hazen, 2006).

\section{Conclusion}

The term 'organomineral' was introduced in the geobiological literature a dozen years before Perry et al. (2007), with basically the same meaning and distinction from biominerals. A new definition is unnecessary, in particular when it introduces confusion detrimental to a fine understanding of geobiological processes and products. The presence of organic matter 
within extraterrestrial or primitive Earth minerals and rocks cannot, by itself, be interpreted as indicative of the existence of life, without taking into account the possible implication of prebiotic organomineral interactions and products. In the other branches of geobiology, the distinction between organic matter that is simply entombed in minerals and organic matter that induces the formation of associated minerals remains fundamental. The discrimination between passive and mineralization-active organic compounds also has practical importance, for example in potential engineering applications of processes of organic-mineral interactions to the design of new materials, the protection and remediation of stone-buildings, natural water and soil remediation, water and wastewater treatment, etc. Instead of quoting Shakespeare's Romeo and Juliet (Perry at al., 2007, pp. 159 and 174), the authors would have gained by drawing inspiration from Don Pedro's address to Claudio in Much Ado About Nothing: "What need the bridge much broader than the flood? The fairest grant is the necessity."

\section{Acknowledgements}

We thank two anonymous reviewers and Editor Brian Jones for their comments on the manuscript.

\section{References}

Arp, G., Reimer, A., Reitner, J., 1999. Calcification in cyanobacterial biofilms of alkaline salt lakes. European Journal of Phycology 34, 393-403.

Arp, G., Reimer, A., Reitner, J., 2002. Calcification of cyanobacterial filaments: Girvanella and the origin of lower Paleozoic lime mud: Comment. Geology 30, 579-580. 
Arp, G., Reimer, A., Reitner, J., 2003. Microbialite formation in seawater of increased alkalinity, Satonda Crater Lake, Indonesia. Journal of Sedimentary Research 73, 105-127.

Bengtson, S., 1994. The advent of animal skeletons. In: Bengtson, S. (Ed.), Early Life on Earth. Nobel Symposium $N^{\circ}$ 84. Columbia University Press, New York, United States of America, pp. 412-425.

Camoin, G.F., Gautret, P., Montaggioni, L.F., Cabioch, G., 1999. Nature and environnemental significance of microbialites in Quaternary reefs: the Tahiti paradox. Sedimentary Geology $126,271-304$.

Cisar, J.O., Xu, D.Q., Thompson, J., Swaim, W., Hu, L., Kopecko, D.J., 2000. An alternative interpretation of nanobacteria-induced biomineralization. Proceedings of the National Academy of Sciences of the United States of America 97, 11511-11515.

Davies, S.A., Dujardin, E., Mann, S., 2003. Biomolecular inorganic materials chemistry. Current Opinion in Solid State and Materials Science 7, 273-281.

Défarge, C., Trichet, J., 1995. From biominerals to 'organominerals': The example of the modern lacustrine calcareous stromatolites from Polynesian atolls. In: Allemand, D., Cuif, J.P. (Eds.), Proc. 7th Int. Symp. Biomineralization. Bulletin de l'Institut Océanographique de Monaco, nº spéc. 14, vol. 2, pp. 265-271.

Défarge, C., Trichet, J., Jaunet, A.M., Robert, M., Tribble, J., Sansone, F.J., 1996. Texture of microbial sediments revealed by cryo-scanning electron microscopy. Journal of Sedimentary Research 66, 935-947.

Delecat, S., Peckman, J., Reitner, J., 2001. Non-rigid cryptic sponges in oyster patch reefs (Lower Kimmeridgian, Langenberg/Oker, Germany). Facies 45, 231-254.

Dujardin, E., Mann, S., 2002. Bio-inspired materials chemistry. Advanced Materials 14, 775788. 
Dupraz, C., Visscher, P.T., 2005. Microbial lithification in marine stromatolites and hypersaline mats. Trends in Microbiology 13, 429-438.

Dupraz, C., Visscher, P.T., Baumgartner, L.K., Reid, R.P., 2004. Microbe-mineral interactions: early carbonate precipitation in a hypersaline lake (Eleuthera Island, Bahamas). Sedimentology 51, 745-765.

Fischer, R., Pernet, B., Reitner, J., 2000. Organomineralization of cirratulid annelid tubes Fossil and Recent examples. Facies 42, 35-50.

Gautret, P., Trichet, J., 2005. Automicrites in modern stromatolitic deposits of Rangiroa, Tuamotu Archipelago, French Polynesia: Biochemical parameters underlaying their formation. Sedimentary Geology 178, 55-73.

Gautret, P., Camoin, G., Golubic, S., Sprachta, S., 2004. Biochemical control of calcium carbonate precipitation in modern lagoonal microbialites, Tikehau atoll, French Polynesia. Journal of Sedimentary Research 74, 462-478.

Golubic, S., Radoičic, R., Seong-Joo, L., 2006. Decastronema kotori gen. nov., comb. nov.: a mat-forming cyanobacterium on Cretaceous carbonate platforms and its modern counterparts. Carnets de Géologie / Notebooks on Geology, Article 2006/02.

Harrison, C.C., Shaw, P.A., 1995. Bacterial involvement in the production of silcretes? In: Allemand, D., Cuif, J.P. (Eds.), Proc. 7th Int. Symp. Biomineralization. Bulletin de l'Institut Océanographique de Monaco, n spéc. 14, vol. 2, pp. 291-295.

Hazen, R.M., 2006. Mineral surfaces and the prebiotic selection and organization of biomolecules. American Mineralogist 91, 1715-1729.

Kirkland, B.L., Lynch, F.L., Rahnis, M.A., Folk, R.L., Molineux, I.J., McLean, R.J.C, 1999. Alternative origins for nannobacteria-like objects in calcite. Geology 27, 347-350. 
Kirschvink, J.L., Hagadorn, J.W., 2000. A Grand Unified Theory of Biomineralization. In: Bäuerlein, E. (Ed.), The Biomineralization of Nano- and Micro-Structures. Wiley-VCH Verlag GmbH, Weinheim, Germany, pp. 139-150.

Lowenstam, H.A., Weiner, S., 1989. On Biomineralization. Oxford University Press, Oxford. Naylor, L.A., 2005. The contributions of biogeomorphology to the emerging field of geobiology. Palaeogeography, Palaeoclimatology, Palaeoecology 219, 35-51.

Nealson, K., Ghiorse, W.A., 2001. Geobiology: Exploring the Interface between the Biosphere and the Geosphere. A Report from the American Academy for Microbiology, Washington D.C.

Neuweiler, F., Gautret, P., Thiel, V., Lange, R., Michaelis, W., Reitner, J., 1999. Petrology of Lower Cretaceous carbonate mud mounds (Albian, N. Spain): insights into organomineralic deposits of the geological record. Sedimentology 46, 837-859.

Perry, R.S., Mcloughlin, N., Lynne, B.Y., Sephton, M.A., Oliver, J.D., Perry, C.C., Campbell, K., Engel, M.H., Farmer, J.D., Brasier, M.D., Staley, J.T., 2007. Defining biominerals and organominerals: Direct and indirect indicators of life. Sedimentary Geology 201, 157-179.

Pratt, B.R., 2001. Calcification of cyanobacterial filaments: Girvanella and the origin of lower Paleozoic lime mud. Geology 29, 763-766.

Reitner, J., 2004. Organomineralization: a clue to the understanding of meteorite-related "bacteria-shaped" carbonate particles. In: Seckbach, J. (Ed.), Origins. Genesis, Evolution and Diversity of Life. Kluwer Academic Publishers, Dordrecht, The Netherlands, pp. 195-212. Reitner, J., 2005. Calcifying extracellular mucus substances (EMS) of Madrepora oculata - a first geobiological approach. In: Freiwald, A., Roberts, J.M. (Eds.), Cold-Water Corals and Ecosystems. Springer-Verlag, Berlin, Germany, pp. 731-744. 
Reitner, J., Arp, G., Thiel, V., Gautret, P., Galling, U., Michaelis, W., 1997. Organic matter in Great Salt Lake ooids (Utah, USA) - First approach to a formation via organic matrices. Facies 36, 210-219.

Riding, R., 2000. Microbial carbonates: the geological record of calcified bacterial-algal mats and biofilms. Sedimentology 47 (Suppl. 1), 179-214.

Russo, F., Gautret, P., Mastrandea, A., Perri, E., 2006. Syndepositional cements associated with nannofossils in the Marmolada Massif: Evidences of microbially mediated primary marine cements? (Middle Triassic, Dolomites, Italy). Sedimentary Geology 185, 267-275.

Schlager, W., 2003. Benthic carbonate factories of the Phanerozoic. International Journal of Earth Sciences 92, 445-464.

Sprachta, S., Camoin, G., Golubic, S., Le Campion, T., 2001. Microbialites in a modern lagoonal environment: nature and distribution, Tikehau atoll (French Polynesia). Palaeogeography, Palaeoclimatology, Palaeoecology 175, 103-124.

Tribovillard, N., Trichet, J., Défarge, C., Trentesaux, A., 1999. Jurassic lagoonal environments and quasi-abiotic platy limestone accumulation: microbial interventions. Sedimentology 46, 1183-1197.

Tribovillard, N., Trentesaux, A., Trichet, J., Défarge, C., 2000. A Jurassic counterpart for modern kopara of the Pacific atolls: lagoonal, organic matter-rich, laminated carbonate of Orbagnoux (Jura Mountains, France). Palaeogeography, Palaeoclimatology, Palaeoecology $156,277-288$

Trichet, J., 1995. Introduction to the session Free organic compounds. In: Allemand, D., Cuif, J.P. (Eds.), Proc. 7th Int. Symp. Biomineralization. Bulletin de l'Institut Océanographique de Monaco, $\mathrm{n}^{\circ}$ spéc. 14, vol. 2, pp. 201-202. 
Trichet, J., Défarge, C., 1995. Non-biologically supported organomineralization. In: Allemand, D., Cuif, J.P. (Eds.), Proc. 7th Int. Symp. Biomineralization. Bulletin de l'Institut Océanographique de Monaco, n spéc. 14, vol. 2, pp. 203-236.

Trichet, J., Défarge, C., Tribble, J., Tribble, G., Sansone, F., 2001. Christmas Island lagoonal lakes, model for the deposition of carbonate - evaporite - organic laminated sediments. Sedimentary Geology 140, 177-189.

Vali, H., McKee, M.D., Çiftçioglu, N., Sears, S.K., Plows, F.L., Chevet, E., Ghiabi, P., Plavsic, M., Kajander, E.O., Zare, R.N., 2001. Nanoforms: a new type of protein-associated mineralization. Geochimica et Cosmochimica Acta 65, 63-74.

Westall, F., Steele, A., Toporski, J., Walsh, M., Allen, C., Guidry, S., McKay, D., Gibson, E., Chafetz, H., 2000. Polymeric substances and biofilms as biomarkers in terrestrial materials: Implications for extraterrestrial samples. Journal of Geophysical Research 105, 24511-24527. Winsborough, B.M., 2000. Diatoms and benthic microbial carbonates. In: Riding, R.E., Awramik, S.M. (Eds.), Microbial Sediments. Springer-Verlag, Berlin, Germany, pp. 76-83. 